\title{
A OCITOCINA COMO AGENTE INDUTOR À PARTURIÇÃO DE ÉGUAS COM PRENHEZ PROLONGADA (Oxytocin as a parturition induction factor on delayed pregnancy by mares) \\ R.R. WEISS ${ }^{1}$; L.E. KOZICKI ${ }^{1}$; A. BUSATO ${ }^{2}$; C. MESSIAS ${ }^{3}$
}

${ }^{1}$ Professores do Departamento de Medicina Veterinária da Universidade Federal do Paraná. ${ }^{2}$ Médica Veterinária. Curitiba (PR). ${ }^{3}$ Pós-Graduação em Ciências Veterinárias da Universidade Federal do Paraná.

O presente trabalho objetivou avaliar a ocitocina como fator de indução à parturição em éguas com prenhez prolongada. Foram utilizadas 18 éguas da raça Puro Sangue Inglês (PSI) que encontravam-se além dos 350 dias de gestação e apresentavam sinais iniciais de toxemia gravídica. Para a indução ao parto foram administradas 50 UI de ocitocina (IM). Em torno de 28 minutos após a aplicação do hormônio, os animais demonstraram aumento de temperatura cutânea, sudorese, inquietude e olhar em direção ao flanco, intensa presença de secreção colostral e finalmente contrações partais. Os dados colhidos estão expostos na tabela abaixo.

Tabela 1. Alguns parâmetros partais e puerperais após administração de ocitocina em éguas puro sangue inglês com gestação prolongada. ( $\mathrm{n}=18)$.

\begin{tabular}{c|c|c|c|c|c}
\hline $\mathrm{N}^{\text {o }}$ de animais & $\begin{array}{c}\text { Duração } \\
\text { gestação (dias). }\end{array}$ & $\begin{array}{c}\text { Início do parto após } \\
\text { administração } \\
\text { da } \\
\text { ocitocina, em minutos. }\end{array}$ & $\begin{array}{c}\text { Duração do parto. } \\
\text { Intervalo em } \\
\text { minutos. }\end{array}$ & $\begin{array}{c}\text { Expulsão da } \\
\text { Placenta. Intervalo } \\
\text { em minutos. }\end{array}$ & $\begin{array}{c}\text { Vitalidade fetal. } \\
\text { Intervalo em (\%). }\end{array}$ \\
\hline 2 & 350 & $20-30$ & $19-22$ & $60-96$ & Vivos \\
4 & 360 & $26-30$ & $26-32$ & $66-90$ & Vivos \\
4 & 361 & $21-29$ & $18-28$ & 8090 & Vivos \\
3 & 362 & $18-28$ & $25-30$ & $70-105$ & Vivos \\
$1^{*}$ & 367 & $24-31$ & $21-31$ & 180 & Vivos \\
\hline$(\mathrm{x} \pm \mathrm{s})$ & $359,5 \pm 5,1$ & $28,7 \pm 14,1$ & $28,0 \pm 10,5$ & $84,2 \pm 28,0$ & 94,4 \\
\hline
\end{tabular}

* Clinicamente o animal não apresentou os sinais característicos da fase de preparação ao parto, ocorrendo distocia fetal com posterior prolapso vaginal total.

Frente a estes resultados pode-se concluir que o parto em éguas PSI pode ser terapêuticamente provocado com elevado percentual de sucesso desde que seja observado: a)- gestação com um mínimo de 350 dias para garantir a sobrevida fetal. b)a realização de minucioso exame obstétrico visando principalmente a correta estática fetal. c)- um favorável prognóstico obstétrico com vistas ao suficiente grau de abertura das vias fetais mole e dura. 